\section{MOLNÁR ANNA}

ny. egyetemi docens

Debreceni Egyetem BTK

Germanisztikai Intézet

annamol0226@.gmail.com

\section{VIRÁGOS MÁRTA}

tudományos fömunkatárs

Debreceni Egyetem Informatikai Kar

viragos.marta@inf.unideb.hu

\title{
PUKÁNSZKY BÉLA GERMANISTA PROFESSZOR, A DEBRECENI TUDOMÁNYEGYETEM 1948-49. TANÉVI REKTORA
}

Pukánszky Béla irodalomtörténész, germanista, az MTA levelezö tagja, 1941-töl haláláig volt a debreceni egyetem professzora, az egyetem Német Irodalom Tanszékét vezette, az 1947/48-as tanévben a bölcsészkar dékánja, az 1948/49-es akadémiai évben az egyetem rektora volt. Sajnálatosan korán, 55 éves korában bekövetkezett halála miatt mindössze kilenc évet dolgozott a debreceni egyetemen, de tudományos munkássága révén messze az egyetem falain túl is ismert és elismert volt.

Kulcsszavak: egyetemtörténet, Debreceni Tudományegyetem, Pukánszky Béla, germanista profeszszor, német-magyar irodalmi kapcsolatok, magyarországi németek

Béla Pukanszky, Professor of German Studies the Rector Magnificus of the Hungarian Royal IstVÁN Tisza UNIVERSITY of DeBRECEN DURING tHE ACADEMIC YeAR 1948/49. Béla Pukánszky, Literary historian. germanist, corresponding member of the Hungarian Academy of Sciences, was a professor at the University of Debrecen from 1941 until his death. He was the Head of the Department of German Literature at the university; he was dean of the Faculty of Arts in the academic year of $1947 / 48$ and rector of the university in the academic year of 1948/49. Due to his unfortunate, early death at the age of 55, he worked at the University of Debrecen for only nine years, but he was known and recognized far beyond the walls of the university through his scholarly work.

Keywords: university history, University of Debrecen, germanist professor, German-Hungarian literary relations, German ethnic groups in Hungary

Beérkezett: 2021. 08. 15.

Közlésre elfogadva: 2021. 10. 15.

Copyright GERUNDIUM 


\section{Élete}

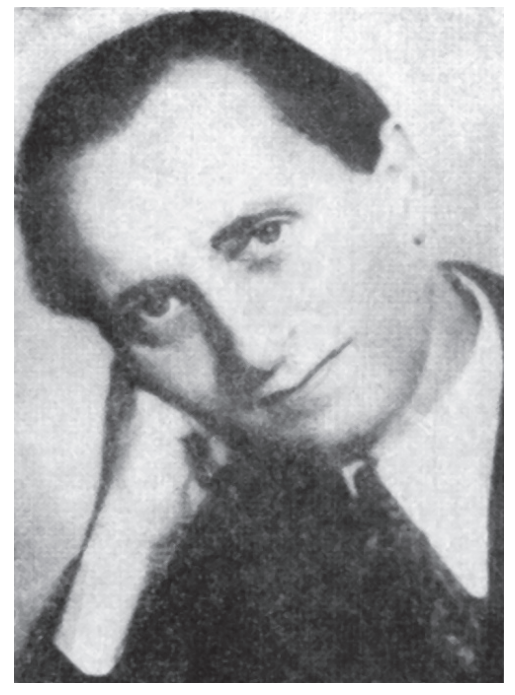

1. kép. Pukánszky Béla (1895-1950) Forrás: DEA

Pukánszky Béla életéről és munkásságáról a legrészletesebb leírást Némedi Lajos irodalomtörténész professzortól ismerjük. A Kossuth Lajos Tudományegyetem Germanisztikai Intézetének 1965-ben megjelent első aktája, a Némedi professzor által szerkesztett Német Filológiai Tanulmányok/Arbeiten zur Deutschen Philologie előszavában a szerkesztő az egész kötetet Pukánszky Béla emlékének ajánlja. Egyúttal egy hosszú tanulmányban ${ }^{1}$ méltatja elődjét. Némedi professzor rövid ideig munkatársa is volt Pukánszkynak, ${ }^{2}$ így a tanulmány néhány személyes vonást is felvillant a tudós professzorról. E tanulmányból így bontakozik ki előttünk Pukánszky Béla élete:

1895-ben Pozsonyban született értelmiségi családban. Édesapja teológiai tanár, a héber nyelv professzora. A szülői ház biztonságát és szellemiségét azonban nagyon rövid ideig élvezhette, hiszen szülei halála után, már 1899-ben a pozsonyi evangélikus árvaházba, majd az ottani evangélikus líceumba került. Itt gondos nevelést kap, a kiválóan tanuló ifjút támogatják, hogy érdeklődésének megfelelő képzést kapjon. Elsősorban a művészetek vonzzák, színház- és zenekedvelő, sőt művészi pályára, hegedűsnek készül. 1914-ben érettségizik, ám mégsem zenei pályára megy, hanem a budapesti bölcsészkar magyar-német szakára iratkozik be. Egyúttal felvételt nyer az Eötvös Kollégiumba, abba a tehetséggondozó intézménybe, amely a 20. század első felében a magyar szellemi elitet kinevelte. Egész életében hálával gondol az Eötvös Kollégiumra, Némedi professzor szerint még a debreceni évei alatt is sokat mesél kollegáinak az ottani szellemiségről, diákok és professzorok közötti derűs és inspiráló viszonyról. ${ }^{3}$

1918-ban készül el doktori disszertációja Herder hazánkban ${ }^{4}$ címmel, amelyet „sub auspiciis regis" minősítéssel fogadnak el.

1922-től 13 évig a budapesti egyetem közgazdasági karán német nyelvet tanít, de közben módja nyílik arra is, hogy 1922/23-ban germanisztikai és filozófiai kutatásokat folytasson a berlini és a müncheni egyetemen.

${ }^{1}$ Lajos NÉmedi, „Béla Pukánszky”, Német Filológiai Tanulmányok 1(1965): 9-28.

${ }^{2}$ Némedi Lajos, szerk. Szecskó Károly, Tudós tanárok - tanár tudósok (Budapest: Országos Pedagógiai Könyvtár és Múzeum, 2014), 40.

3 NÉmedi, „Béla Pukánszky”, 10.

${ }^{4}$ PukÁnszky Béla, „Herder hazánkban (Herder in Ungarn): 1. Herder és a népies irány (Herder und die volkstümliche Richtung)" Német Philológiai Dolgozatok 23(1918): 119. 
1924-ben megnősül, felesége Kádár Jolán színháztörténész.

Berlini és müncheni tanulmányútja lendületet ad tudományos munkája itthoni folytatására, ennek eredményeként 1927-ben habilitál a budapesti egyetemen az újabb német, elsősorban osztrák irodalom tárgykörében. Ettől kezdve egyetemi magántanárként előadásokat tart a budapesti egyetem Német Irodalom tanszékén. Tudományos teljesítménye elismeréseként a Magyar Tudományos Akadémia 1932-ben levelező tagjává választja.

1935-ben otthagyja a közgazdasági karon végzett nyelvtanári állását, kinevezik a budapesti egyetem bölcsészkara mellett működő Tanárképző Intézet professzorává. Egy szívéhez igen közel álló feladatra is lehetősége nyílik, előadásokat tarthat az Eötvös Kollégiumban.

1941-ben meghívást kap a debreceni egyetemre, ettől kezdve haláláig az itteni Német Irodalom Tanszék professzora, de megtartja korábban Budapesten vállalt kötelezettségeit: 1932-től a budapesti Philológiai Társaság első titkára, 1941 és 1944 között főszerkesztője a Magyar-Német Társaság Ungarn című kulturális folyóiratának. Ez az 1940 és 1944 között havonta megjelent folyóirat a magyar-német kulturális kapcsolatok fóruma, kultúrtörténeti, művészettörténeti, régészeti, irodalomtörténeti, történelmi, szociológiai témájú cikkeket és szépirodalmat közölt. ${ }^{5}$

A háborús évek alatt Pukánszky Budapesten lakik a családjával, hetente utazik Debrecenbe, 1945-ben tér vissza az újra megnyíló egyetemre. Ekkor nehéz és méltatlan időszak következik az életében. Mint az egyetem minden professzorának, neki is igazolnia kell, hogy nem az új rendszer ellensége és a múltjában nincs olyan momentum, ami az elmúlt rendszer hívének mutatja. Az igazolóbizottság, majd a népbíróság elé állítják, felróva neki, a germanistának (!) a németekhez füződő kapcsolatait, a Magyar-Német Társaságban végzett munkáját, az Ungarn címủ folyóirat szerkesztését. A majdnem állásvesztéssel járó eljárást - Szabó Árpád klasszika-filológia professzor mellette kiálló erőteljes fellépésének köszönhetően is - fellebbezés után megszüntetik, folytathatja egyetemi tanári munkáját. ${ }^{6}$

Pukánszky 1947/48-ban a bölcsészkar dékánja, 1948/49-ben az egyetem rektora. Rektori székfoglaló beszéde egy emelkedett hangú értekezés ${ }^{7}$ Goethe Faustjának belső átalakulásáról, arról, miként halad Faust, folyton változva a teljes emberiesség felé. Pukánszky értekezésének középpontjában a metamorfózis áll, a megmaradás elvével szemben a változás. A metamorfózist, a megújhodás képességét és szükségességét állítja erkölcsi követelményként minden tevékenység, így saját rektori éve elé is. Egy

5 „Ungarn. Monatschrift für deutsch-ungarischen Kulturaustausch der ungarisch-deutschen Gesellschaft in Budapest, Budapest-Leipzig-Milano, Aug. 1940. - Okt. 1944. Jg. 5. Red. Béla PUKÁNsZKY. Monatlich / Quart. Inhalt: Kulturgeschichte, Kunstgeschichte, Archaeologie, Literaturgeschichte, Geschichte, Soziologie, Belletristik." Vö. Deutschsprachige Presse in Ungarn - Magyarországi német sajtó 1921-2000. Bibliographie/Bibliográfia, Összeáll. Rózsa Mária (Budapest: Országos Széchényi Könyvtár-Gondolat Kiadó, 2006), 63.

${ }^{6}$ A Debreceni Egyetem Bölcsészettudományi Karának története I., szerk. PAPP Klára (Debrecen: DE BTK, 2014), 114-115.

7 Pukánszky Béla, Faust metamorfózisa, DEENK, Kézirattár Ms 29/1. 
humanista tudós keresi itt - igen magas absztrakciós szinten - a kapcsolódást az új világhoz is, aminek egyik kulcsszava épp a „haladás” volt. Pukánszkyra rektorként nehéz, szellemi alkatától meglehetősen idegen feladat vár, elkezdeni az egyetem haladóvá, szocialistává alakítását. Ráadásul meg kell tapasztalnia, hogy a politikai irányítás alatt álló tudományos közélet továbbra is megbízhatatlannak tartja, 1949-ben megfosztják akadémiai tagságától. Ezt a szégyenteljes aktust csak 1989-ben tette semmissé az Akadémia, amikor is visszaállították Pukánszky professzor akadémikusságát. De ezt ő már nem érhette meg, 1950-ben szívelégtelenségben meghalt, a Farkasréti temetőben nyugszik.

\section{A tudós germanista}

Pukánszky tudományos érdeklődésének középpontjában a magyar-német szellemi és irodalmi kapcsolatok, a magyarországi német irodalom és az újkori német és osztrák irodalom állt.

Az 1918-ban írt Herder hazánkban címủ doktori disszertációjával ${ }^{8}$ kezdődik az a tanulmánysorozat, amelynek darabjai a német filozófia és irodalom magyarországi recepciójával foglalkoznak. A disszertációban Herdernek a népköltészetről, a népdalról írt elméleti fejtegetéseit mutatja be és e gondolatok megjelenését követi a magyar irodalomban a 18. század második felétől, Csokonainál, Kölcseynél, Kazinczynál, Toldy Ferencnél és Erdélyi Jánosnál. A német kultúra magyarországi fogadtatásáról írt további tanulmányaiban elemzi Schopenhauer hatását a 19. század végi magyar lírára," tanulmányt ír a magyar Kant-követőkről, ${ }^{10}$ Lessing és Kazinczy kapcsolatáról, ${ }^{11}$ Lenau magyar vonatkozásairól ${ }^{12}$ és természetesen a magyar Goethe-kultuszról. ${ }^{13} \mathrm{~A}$ felsorolt írások jól mutatják, hogy Pukánszky számára az eszmetörténeti kapcsolódások éppoly fontosak, mint az összehasonlító irodalmi látásmód. Tudományos életművének máig leginkább ismert és idézett két munkájában a magyarországi német irodalommal és a magyarországi német polgársággal foglalkozik. E téma iránti elkötelezettsége és az ebből következő kutatási program már a fent idézett disszertációja előszavából kiviláglik: „A hazai németség irodalmának, mint a magyarral közös talaj gyümölcsének tekintetbevételét egyik fókötelességemnek tartottam, [...] E hazai német irodalom részletes ismerete elengedhetetlen kelléke nemzeti irodalmunk helyes megértésének. "14

${ }^{8}$ Pukánszky Béla, Herder hazánkban I. Herder és a népies irány. Irodalomtörténeti tanulmány, Német Philológiai Dolgozatok 23. (Budapest, 1918)

9 Pukánszkr Béla, „Schopenhauer és a század végi magyar líra”, Minerva (1922): 241-251.

${ }^{10}$ Pukánszky Béla, „Kant első magyar követői és ellenfelei”, Protestáns Szemle (1924): 294-303.

11 Pukánszky Béla, „Lessing und Franz von Kazinczy”, Deutschungarische Heimatblätter (1929): 71-79.

12 Pukánszkr Béla, „Lenau és a magyar föld”, in Emlékkönyv Berzeviczy Albert, a MT Akadémia elnökének tiszteleti taggá választásának harmincadik évfordulója alkalmából (Budapest: Franklin, 1934), 200-211.

13 Pukánszky Béla, „Goethekultus in Ungarn und die Goethesammlung in Budapest”, in Uo, Deutschungarische Begegnungen (Budapest: Danubia Kiadó, 1943), 118-125.

14 Pukánszky Béla, Herder hazánkban, 4. 
Az elköteleződést személyes okok is motiválják: Pukánszky Pozsonyból származik, ott járt iskolába, születésétől fogva kétnyelvü, mint a város lakóinak nagy része ebben az időben.

1926-ban jelent meg a Pukánszky főművének tartott, A magyarországi német irodalom története (a legrégibb idöktöl 1848-ig) ${ }^{15}$ címü, több mint 600 oldalas munkája. A mü egy addig nem kutatott témát, a Magyarországon élő németek irodalmának történetét írja meg a 19. század közepéig. A témaválasztás azért úttörö, mert a 19. század végén megindult magyarországi germanisztikai kutatások elsősorban a magyarországi németek nyelvére, a magyarországi német nyelvjárásokra koncentráltak. A német irodalom fejlődését Pukánszky nem szokványos keretben mutatja be, mert meggyőződése, hogy a magyarországi németség irodalmát nem elsősorban a németországi irodalom, hanem a magyar nemzeti irodalom kontextusában, azzal való kölcsönhatásban lehet csak értelmezni (lásd a fenti idézetet is!). Nagy körültekintéssel gyüjti össze a magyarországi németség írásos emlékeit. Könyve nem a magyarországi német szépirodalom története, a tartalom sokkal inkább a mủ német címének felel meg: A magyarországi német írásbeliség emlékeit mutatja be. Ezt a nézőpontot a mű előszavában így indokolja:

\begin{abstract}
„A nagy német irodalomban hazai német íróink természetesen csak nagyon szerény helyet kapnak. Esztétikai szempontok merev érvényesítése anyagunkat néhány munkára szorítaná. Az irodalomtudomány azonban ma már nem áldozza fel az irodalmi emlékeket pusztán esztétikai szempontoknak. A német szellemi élet főbb irányainak recepciójához és a messze szétágazó német nép jellemének megismeréséhez pedig gazdag adalékokat nyújt a magyarországi német irodalom. Ez nemcsak jogosulttá, hanem szükségessé teszi német szempontból is a vele való foglalkozást. Magyar talajon és a magyar történeti hagyományok ismeretében felnőtt német íróink minden új eszmét saját hagyományaik és szellemi szükségleteik szerint értékesítették." ${ }^{16}$
\end{abstract}

A könyv felvázolja azt a történelmi-társadalmi hátteret is, amelyben az itt élő németek szellemi produktumai megszülettek. Képet kapunk e népcsoport település- és iskolatörténetéről, társadalom-, vallás- és mentalitástörténetéről is. Az irodalom műfajai közé ezért bekerülnek például a magyarországi németek jogszolgáltatásának dokumentumai, a jogkönyvek, számadáskönyvek, oklevelek, de a kalendáriumok, imádságos könyvek, vallásos oktató iratok is. Pukánszky nagy szakirodalmi apparátussal támasztja alá állitásait, minden fejezet végén bőséges irodalomjegyzéket nyújt az olvasónak.

15 PukÁnszky Béla, A magyarországi német irodalom története (a legrégibb idöktöl 1848-ig), (Geschichte des deutschen Schrifttums in Ungarn von der ältesten Zeit bis 1848) Német Philológiai Dolgozatok 31. (Budapest: Budavári Tudományos Társaság, 1926).

16 Uo., 6-7. 
A magyarországi németséggel foglalkozó másik alapvető munka a Német polgárság magyar földön, ${ }^{17}$ ami 1940-ben jelent meg. Ez a könyv a Magyarországon élö német polgárság mentalitástörténetét írja meg, de nem a német betelepülések kezdetétől, a 12 . századtól, hanem a 19. század közepétől. Ennek az az oka, hogy Európában a nemzeti identitások kialakulásának ideje a 19. század, ekkor váltja fel az állampatriotizmust a nemzeti gondolat és érzület, a nemzethez való hűség morális követelménye. A magyarországi németek is ekkortól kezdik magukat önálló etnikumként definiálni:

„A történelmi folyamat, melyet áttekintünk, időben és térben elhatárolt. Időben: a magyarországi német polgárság csak a felvilágosodás nyomában támadó nacionalizmus hatása alatt ébred lassankint népi különvalóságának tudatára, ekkor kezd gondolkodni a magyar-német együttélés lehetőségeiről.”18

E „különvalóságból” két stratégia adódik az itt élő németek számára: az asszimiláció, a magyar társadalomba való beolvadás vagy a disszimiláció, az attól való elkülönülés. Pukánszky e két stratégia megvalósulását mutatja be ebben a könyvében. Az asszimiláció az itt élő németek számára a 19. században a felemelkedés útját jelenti:

„Polgárságunk a városokban együtt élt a magyar nemességgel: nemcsak a szabadkőműves páholyok zárt, magasabb szellemiségü világa, hanem a hétköznapnak szinte minden lépése is elébe tárta ennek a nemességnek gondolkodását, egész életstílusát. A társadalmi felemelkedés vágya ezt az életstílust eszménnyé szépítette, áhítattal bámult mintaképpé emelte. A mintakép követése pedig a polgárság számára szükségképpen a magyarság javára bontotta meg az állampatriotizmusban egyesített népek rangegyenlőségét. A nemes úr volt, mégpedig magyar úr: ki ne szeretett volna hát hozzá hasonlóvá lenni? Az úriság és magyarság fogalma a századforduló körül lassanként éppen úgy azonosult, éppen olyan hatékony vonzóerőnek bizonyult, mint 1867 után." ${ }^{19}$

Míg az asszimiláció elsősorban a német polgári réteg útja, addig a kiegyezés után meginduló disszimiláció Pukánszky szerint egy másik társadalmi réteget érint és jóval szerényebb mértékű. Az elkülönülés gondolata nem a nagyvárosokban, hanem a németek lakta kisvárosokban, falvakban, a paraszti rétegben talál követőkre.

„A paraszti és a német népi öntudat későb is együtt jelenik meg a bánáti németségnél. Fordított előjellel ugyanazt a folyamatot látjuk itt, mint a föváros és

${ }_{17}$ Pukánszky Béla, Német polgárság magyar földön, Magyarságismeret 4. (Budapest: Franklin, 1940); Újra kiadva Niederhauser Emil tanulmányával. Kisebbségkutatás Könyvek (Budapest, Lucidus Kiadó, 2000).

18 Uo., 6.

19 Uo., 21. 
a nyugati végek városainak polgárságánál. Míg Pesten, Pozsonyban, Sopronban a polgári öntudattal együtt a német érzület is kivész, addig Versecen, Nagykikindán, Fehértemplomban egymást erősíti a paraszti és német népi öntudat."20

A disszimiláció legerősebben az erdélyi szászoknál mutatkozik, akiknek Pukánszky 1943-ban külön könyvet szentel: Erdélyi szászok és magyarok címmel. ${ }^{21}$ Annál is inkább, mivel elöző könyvében, a Német polgárság magyar földön címüben az erdélyi szászokkal nem foglalkozott. Ezt így indokolja:

\begin{abstract}
„Az erdélyi szászok mindig külön egységet alkottak a magyarországi németségen belül. Kivételes közjogi helyzetük, viszonyuk Erdély többi népeihez és titokzatos elzárkózásuk más irányt szabott fejlődésüknek. Különálló politikai és szellemi életük, sajátos történelmi tudatuk elősegítette a német népi öntudat kialakulását, de útját állta annak, hogy a magyarsághoz való viszonyában ugyanazon vagy hasonló helyzetek adódjanak mint a szűkebb haza német polgárságánál.”22
\end{abstract}

Pukánszky e népcsoport különállóságát, a magyar, sőt a többi magyarországi német népcsoporttól való elzárkózását, erős német népi öntudatát mutatja be, és keresi a választ az okokra. A magyarázatot abban találja meg, hogy az Erdélyben már a 12. században megtelepedett szászok a magyar királyoktól kiváltságokat kaptak, zárt földrajzi egységben szervezték meg a saját közigazgatásukat, egyházi életüket, önálló iskolarendszerüket; Németországgal való kapcsolatukat pedig - szemben a magyarországi németek más csoportjaival - mindig fontosnak tekintették és folyamatosan fenntartották.

Pukánszkyt a magyar-német szellemi és kulturális kapcsolatok kutatásán túl a szorosabban vett német irodalomtörténet, elsősorban a modern német és osztrák irodalom érdekli. Cikket ír a kortárs német líráról ${ }^{23}$ és a modern német regényről, ${ }^{24}$ ez utóbbiban Thomas Mann, Franz Werfel és Jakob Wassermann valóságábrázolásáról és írásművészetéről értekezik. Hosszú tanulmányt jelentet meg a kortárs osztrák irodalomról, ${ }^{25}$ amelyben megkíséreli elméletileg is megadni azokat a fogódzókat, amelyek alapján ez az irodalom elkülöníthető a (birodalmi) német irodalomtól.

Talán a korabeli germanisták által leggyakrabban forgatott könyve $A$ német irodalom kis tükre, ${ }^{26}$ egy 80 oldalas, akkoriban hiányt pótló könyvecske, a német irodalom történetének rövid összefoglalása a középkortól az expresszionizmusig.

\footnotetext{
20 Uo., 207.

21 Pukánszky Béla, Erdélyi szászok és magyarok (Pécs: Danubia Kiadó, 1943); Újra kiadva 2004-ben az Attraktor Kiadónál.

22 PukÁnszky, Német polgárság magyar földön, 7.

23 Pukánszky Béla, „A mai német líra”, Magyar Szemle 10. (1930): 369-374

24 Pukánszky Béla, A mai német regény”, Magyar Szemle 14. (1932): 22-29.

25 Pukánszky Béla, A mai osztrák irodalom (Budapest: Franklin Társulat, 1936).

26 Pukánszky Béla, A német irodalom kis tükre (Budapest: Magyar Szemle Társaság, 1930).
} 
A felsorolt irodalomtörténeti tanulmányokból két dolog világosan látszik: Pukánszky missziójának tekintette a kortárs német irodalom megismertetését a magyar olvasóközönséggel. Másfelől többszörösen hangsúlyozza az osztrák-német irodalom különálló voltát, az osztrák irodalom egyedi szellemiségét, ami Rilke, Trakl, Schnitzler vagy Musil munkásságában érhető tetten.

Pukánszky írásai szakszerűségük és tudományos súlyuk mellett élvezetes olvasmányok is, egy remek, irodalmi vénával is megáldott szerző alkotásai.

\section{Pukánszky és a zene}

Az már írásai olvasásakor kiderül, hogy Pukánszky professzor széles látókörü, hatalmas olvasottsággal rendelkező tudós volt. Műveltségének és személyiségének szerves része volt a filozófia és az irodalom mellett a zene is. ${ }^{27}$ Ifjúkora óta a zene büvöletében élt, hangverseny- és operalátogató volt, Pozsonyban, de még Budapesten is hegedülni tanult, sőt sokáig művésznek készült. Oktató- és kutatómunkája mellett debreceni professzorként is szakított időt a zenélésre. Tamusné Molnár Viktória kutatásából tudjuk, hogy Debrecenben is kamarazenélt egy kvartettben:
„Debrecenben is sokat szonátázott Uray Magdolnával, volt egy kvartettje Gosz- tonyi Béla MÁV ügyeletigazgató, Eisler Géza bőrgyógyász és Hahn György szemorvossal. Később zongoratrióban és kvartettben is részt vett, egyszer jóté- kony célból nyilvánosan is felléptek." ${ }^{28}$

Az aktív zenélés mellett a zenei ismeretterjesztés is szívügye volt. Műveinek jegyzékében bőven találunk megjelentetett zenei írásokat is Wagnerrőll, ${ }^{29}$ Beethovenrőll, ${ }^{30} \mathrm{Mo}-$ zartról. ${ }^{31}$ A Debreceni Egyetem Könyvárának Kézirattárában Ms 29 jelzet alatt őrzik azon kéziratainak listáját, amelyeket a család a hagyatékból az egyetem rendelkezésére bocsátott. E 145 tételt felsoroló jegyzék tartalmazza Pukánszky 1948 őszén elmondott rektori székfoglaló beszédét, irodalmi előadások kéziratait és levelezésének egynémely darabját. A 145 tételből a 38-81-ig felsorolt címek zenei ismeretterjesztő előadásainak kéziratait sorolják fel, Mozartról, Beethovenről, a preklasszikus és romantikus zenéről, Debussyről és Chopinről, de Bartókról, Kodályról és Sosztakovicsról is.

${ }^{27}$ Vö. e számunk következő tanulmányát.

28 Molnár-Tamus Viktória, „Művészeti nevelés a debreceni egyetemen 1914-1949 között: Pukánszky Béla professzor (1895-1950) zenei munkássága”, in Válogatott tanulmányok a pedagógiai elmélet és szakmódszertanok köréböl, szerk. KaRLovitz János Tibor (Komarno, International Research Institute, 2017), 47.

${ }^{29}$ Pukánszky Béla, „Wagner a magyar lírában”, Muzsika (1929): 30-33.; Uö, Wagner Richard halálának félszázados évfordulójára. Eötvös füzetek (Budapest-Pécs, 1933).

30 Pukánszky Béla, „Beethoven és Kant”, Athenaeum 25. (1939): 151-165.

31 Pukánszkr Béla, Mozart, A Magyar-Német Társaság Kiadványai 11. (Budapest: Sylvester, 1942). 


\section{A rektori év}

Az 1948/49-es tanévben 17 tanácsülésre került sor. A tanévnyitó ünnepséget október 7-én tartották, az ünnepélyen Bóka László államtitkár vett részt. Ebben az évben már erősen érvényesül a régi rendszer leépítése. Ez egyrészt azokban a miniszteri utasításokban érződik, amelyek például a Horthy-korszakbeli politikusok képmásainak, továbbá szobrok, reliefek, festmények, rajzok, fényképek eltávolítását rendelik el az egyetem épületéből (461. etsz. Vk. Miniszter), vagy a rektori/dékáni jelvények használatának megtiltására és beszolgáltatására szólítanak fel. ${ }^{32}$ Az egyetem vezetői által használt díszruhákat a Magyar Nemzeti Múzeum Történeti Osztályának kellett elküldeni (3140. etsz.). De ennek jele az a tanácsi állásfoglalás is, amely a legnagyobb mértékben elítéli Mindszenthy hercegprímás reakciós álláspontját és teljes mértékben támogatja a kormányt. $^{33}$

Jelentős szervezeti változások következnek be a Debreceni Tudományegyetem életében: megindulnak a matematikai és természettudományi karral kapcsolatos előkészítő munkálatok, melynek vezetésével dr. Tankó Béla egyetemi ny. r. tanár kap megbízást. Az 1949. évi májusi tanácsülésen hivatalosan is bejelentik a Természettudományi Kar megalakulását. Dékáni megbízást dr. Varga Ottó kap, Tankó Béla pedig prodékánként vesz részt a Kari Tanács munkájában. ${ }^{34} \mathrm{~A}$ Tanárképző Intézet és Tanárvizsgáló Bizottság munkáját a Bölcsészettudományi Kar vette át személyzettel és helyiségekkel együtt.

900 aláírással ellátott beadványt küld az egyetem a vallás- és közoktatási miniszternek, hogy a Debreceni Tudományegyetem felvehesse a Kossuth Lajos Tudományegyetem nevet (2176. etsz.).

Pukánszky Béla rektorsága alatt több fegyelmi eljárást is le kellett folytatni magas beosztású egyetemi dolgozókkal szemben. Dr. Tóth Lajos egyetemi gazdasági igazgató és társai ${ }^{35}$ ellen az eljárás 1948 júliusában indult meg, a Fegyelmi Bizottság elnöke Flachbart Ernő, tagjai Pukánszky Béla, Kellner Béla egyetemi ny. r. tanárok és Kerékgyártó János, a Központi Üzemi Bizottság elnöke. Az ügyben 58 tanú kihallgatására került sor. A vád Tóth Lajos ellen: térítésmentes élelmiszer igénylése nagy tételben, saját tulajdonában lévő gépkocsijába az egyetem raktárából való üzemanyag vételezés

32 Az egyetemi díszjelvények történetéről Béres Zsuzsa írt tanulmányt a Gerundium - Egyetemtörténeti Közlemények 2020. 3-4. számában.

${ }_{33}$ Dr. Törő Imre beterjesztése: „Mindjobban kiélezödik a harc, melyet a kormány a klerikális reakció ellen folytat. A magyar egyetemek mind felemelték már tiltakozó szavukat Mindszenthy hercegprímás viselkedésével szemben, amely viselkedés a magyar katholikus egyház és a kormány megegyezésének vet gátat." DEENK Kézirattár. Jegyzőkönyv a Debreceni Tudományegyetem Tanácsának 1948. évi december hó 4-én tartott VI. rendkívüli üléséről. 130. etsz.

${ }^{34}$ A Természettudományi Karhoz került a matematikai, ásvány- és földtani, fizikai tanszékek, valamint a meteorológiai intézet, a csillagvizsgáló intézet, a botanikus kert és az embertani intézet.

35 Tóth Lajos társai: Rozsályi Gergely (egyetemi gazdasági felügyelő), Gaál Imre (gépfelügyelő) és Molnár Árpád (irodasegédtiszt). 
és több egyéb büncselekmény. ${ }^{36} \mathrm{Az}$ Egyetemi Tanács egyhangúlag minden vádlott esetében a hivatalától való megfosztást és pénzbüntetést állapított meg. A másik fegyelmi ügy dr. Mikó Gyula egyetemi nyilvános rendkívüli tanár, valamint Veress Lajos altiszt ellen indult. ${ }^{37} \mathrm{~A}$ vád ellenük tiltott kapcsolat a Rex Gyógyszerészeti Gyárral, ismeretlen eredetű anyagok tárolása, gyógyszertári műszerek gondatlan tárolása. ${ }^{38}$

Dr. Tóth Endre, a Hittudományi Kar dékánja így mondott köszönetet Pukánszkynak rektori évének lezárásakor (a Debreceni Tudományegyetem Tanácsának 1949. évi július hó 19-én tartott XVI. rendes ülésén).

„Magnifice Rector! Az 1948/49. tanév utolsó rendes tanácsülésén az egész Tanács nevében hálás köszönetet mondok Magnificentiádnak ez év rectori munkájáért. - Valóban úgy érzem, hogy képtelen volnék más szót használni, ezt a két elkoptatott szót: hálás köszönet! Mert ha fel akarnám mérni mindazt a nehézségeket, mindazokat a sokszor kínos, sokszor átláthatatlan szövevényủ helyzetet, amiken keresztül Magnificentiád ez éven át vezette a Tanács ügyeit, - úgy gondolom, nem találnék kellő értékủ szavakat, amelyek az elismerés, a méltánylás, a hála és a köszönet érzését kellő képpen kifejezésre tudnák juttatni. - Nem az én feladatom, hogy az elmúlt iskolai év eseményeit végig kísérjem. Eljön az idő rövidesen, amikor Magnificentiád avatott tolla és emelkedett szelleme, szintetikus látása elénk fogja mindezt vetíteni, ami a múlt évről az egyetemi krónika lapjaira kívánkozik. Ha mégis kiragadok az egymásra torlódó eseményből néhányat most, - csak azért teszem, hogy azzal indokoljam mind azt, amit Magnificentiád rectori évével kapcsolatban már említettem. Ez események között egyik oldalon ott állnak a kínos fegyelmi ügyek sorozata, - gazdasági igazgató, tanácsjegyző, questor változás az év folyama alatt, - másik oldalon a nagy ünnepségek, előkelő látogatók fogadása. Bent az egyetemen a bölcsészkar reformja, a természettudományi Kar leválása, a jogi kar beszüneteltetése, kívül a képviseltetések hosszú sora, a helyi szervezetek összejöveteleitől elkezdve, fel a legmagasabb fórumokig. $-S$ ha nem volt nap, mikor Magnificentiádnak szorosan vett rectori teendőinek sokaságát ne kellett volna végezni, - szinte hasonló módon s egyre növekvő arányban hárult Magnificentiádra a teendőknek olyan áradata, amit rectori kötelességein túl kellett végeznie. - És Magnificentiád helyt állott mindenütt s mindig. Magas szellem éles ítélete, mindenütt a helyzet követelte hang azonnali felismerése, a magát nem vonogató szolgálatkészség, segíteni akarás, - az utol nem érhető

36 Tóth Lajos saját telefonszámláját az egyetemmel fizettette meg, külön étlapot állíttatott össze magának és a klinikai étkezésnek 3-4-szeresét vette igénybe. Ládaszám rendelte magának a sört, magánvendégeit nagyrészt az egyetemi főzőkonyháról származó ételekkel vendégelte meg.

${ }^{37}$ Mikó Gyula az egyetemi gyógyszertár vezetője, Veress Lajos gyógyszertári dolgozó.

${ }^{38}$ A gyógyszertárban 100 liter tiszta benzin, 150 liter szesz és 57 liter aceton volt nyilvántartás nélkül, ebből egyébként Mikó a tanszékeknek juttatott ingyen. A gyógyszergyár esetében a vád szerint gyógyszerekkel kísérletezett, és ezért havonta tiszteletdíjat kapott. 
udvarias figyelem, szellemi és fizikai dolgozókkal, diákokkal és professzorokkal szemben, - bölcsesség és józanság, erély és tapintat, - biztos vezetés a tanácskozásokon, beható elmélyedés a problémákban. - S a Tanács tagjai iránt, - ami mindennél több: mindenkor mindenben a megértő támogató jó barát! Mindezekért csak e két szó: hálás köszönet! De azt szeretném, ha megérezné Magnificentiád, hogy e két szó mögött szív van. S éppen ezért ebben a két szóban összesürítve valóban benne van, ami igazi értéke e szavaknak: hála és köszönet! Kérem, fogadja Magnificentiád hálánk és köszönetünk szavának, annak általunk érzett igazi értéke és tartalma szerint!

Kísérje Magnificentiádat további életén áldáskívánságunk!"

Pukánszky professzor élete és tudományos pályája 55 éves korában véget ért, komoly és értékes életművet hagyva az utókorra. A magyarországi németségre vonatkozó munkái a germanisták számára ma is megkerülhetetlenek. Műveltségének és szellemiségének tágassága, tudományos munkájának alapossága és mélysége példaadó. Tudása átadásában, tanárként is mély nyomot hagyott egykori tanítványaiban, nagyrabecsüléssel és szeretettel emlékeztek a kifinomult, nagy műveltségű, művészi hajlamú és mindig közvetlen emberre. Sajnálatos, hogy élete során méltatlan politikai gyanúsítgatás áldozata is volt, holott épp műveltsége, ízlése és polgári humanista attitűdje védte meg attól, hogy a nácizmus szélsőséges ideológiájának hatása alá kerüljön. Tudós germanistaként jóval mélyebb ismeretei voltak a németségről, mint a kor hangos politikai aktorainak. Épp ezért teljességgel hiteltelen és hamis volt az 1945-ben neki felrótt túlzott németbarátság. Pukánszky Béla tudós közvetító volt a magyar és a német kultúra között, mindenkor hivatása magaslatán állt. A Debreceni Egyetem mind tudományos teljesítményére, mind emberi tartására büszke lehet! 